Article

\title{
Effect of Vegetal- and Seaweed Extract-Based Biostimulants on Agronomical and Leaf Quality Traits of Plastic Tunnel-Grown Baby Lettuce under Four Regimes of Nitrogen Fertilization
}

\author{
Ida Di Mola ${ }^{1, *}$, Eugenio Cozzolino ${ }^{2, *}{ }^{\oplus}$, Lucia Ottaiano ${ }^{1}$, Maria Giordano ${ }^{1}(\mathbb{0}$, \\ Youssef Rouphael ${ }^{1}$ (D) Giuseppe Colla ${ }^{3}$ (D) and Mauro Mori ${ }^{1}$ \\ 1 Department of Agricultural Sciences, University of Naples Federico II, Portici 80055, Italy; \\ lucyottaiano@gmail.com (L.O.); maria.giordano@unina.it (M.G.); youssef.rouphael@unina.it (Y.R.); \\ mori@unina.it (M.M.) \\ 2 Council for Agricultural Research and Economics (CREA)-Research Center for Cereal and Industrial Crops, \\ Caserta 81100, Italy \\ 3 Department of Agriculture and Forest Sciences, University of Tuscia, Viterbo 01100, Italy; giucolla@unitus.it \\ * Correspondence: ida.dimola@unina.it (I.D.M.); eugenio.cozzolino@crea.gov.it (E.C.)
}

Received: 3 September 2019; Accepted: 20 September 2019; Published: 22 September 2019

check for updates

\begin{abstract}
Nitrogen $(\mathrm{N})$ fertilizers play a crucial role in agriculture, representing a powerful tool for farmers for increasing yields throughout the seasons under both optimal and suboptimal conditions. At the same time, their synthetic/chemical nature could have several influences on ecosystems and human health. For this reason, there is an urgent need to find new and more sustainable means of production to increase plant productivity and optimize nitrogen use. An experiment was conducted in a plastic tunnel to assess the response of baby lettuce crop to the foliar application of three plant biostimulants (PBs): Legume-derived protein hydrolysate (LDPH) 'Trainer ${ }^{\circledR}$ ', tropical plant extract (TPE) 'Auxym ${ }^{\circledR}$ ' and seaweed extract (SwE) from Ecklonia maxima 'Kelpak ${ }^{\circledR}$ ' under different $\mathrm{N}$ rates of $0,10,20$ and $30 \mathrm{~kg} \mathrm{~N} \cdot \mathrm{ha}^{-1}$. The responses of baby lettuce plants were assessed in terms of yield, growth parameters and physicochemical composition of the leaves. The fresh yield of baby lettuce in both biostimulant-treated and untreated plants was positively affected by increasing $\mathrm{N}$ rates from 0 to $20 \mathrm{~kg} \mathrm{~N} \cdot \mathrm{ha}^{-1}$, reaching a plateau thereafter indicating luxury $\mathrm{N}$ conditions at $30 \mathrm{~kg} \mathrm{~N} \cdot \mathrm{ha}^{-1}$. However, high $\mathrm{N}$ fertilizer application (20 and especially $30 \mathrm{~kg} \mathrm{~N} \cdot \mathrm{ha}^{-1}$ ) resulted in undesirable decreases in antioxidant activities and total ascorbic acid (TAA). Under non-fertilized regimens, foliar PBs application boost growth and yield of baby lettuce in comparison to non-treated plants. Foliar spray with LDPH and especially SwE elicited significant increases in marketable fresh yield (averaging 14\%, $6 \%$ and $7 \%$ at 10,20 and $30 \mathrm{~kg} \mathrm{~N} \cdot \mathrm{ha}^{-1}$, respectively) compared to TPE and untreated plants. Improved agronomical performance of baby lettuce under optimal $\left(10 \mathrm{~kg} \mathrm{~N} \mathrm{ha}^{-1}\right)$ and especially suboptimal $\mathrm{N}$ regimens $\left(0 \mathrm{~kg} \mathrm{~N} \mathrm{ha}{ }^{-1}\right)$ was associated with increasing photochemical efficiency and a better activity of photosystem II (higher Soil Plant Analysis Development-SPAD index and chlorophyllous pigments biosynthesis). The application of LDPH enhanced antioxidant capacity and TAA in baby lettuce leaf and did not increased nitrate content as recorded in SwE and TPE treatments. Overall, plant biostimulants may be considered as a sustainable tool of production to increase leafy vegetable productivity in low fertility soils.
\end{abstract}

Keywords: Lactuca sativa L.; legume-derived protein hydrolysate; nitrate; tropical plant extract; seaweed extract 


\section{Introduction}

In recent years, the consumption of fresh-cut leafy vegetables has increased and among them, baby leaf lettuce is very widespread. Baby leaf lettuce is widely cultivated in Italy under both open field and greenhouse conditions [1]. Baby leaf vegetables are characterized by a short cycle but it requires a correct agronomic management to avoid high levels of nitrate accumulation and pesticide residues in the final product [2]. Therefore, there is a paramount interest in enhancing its production and quality, and at the same time reducing the nitrate levels of leafy vegetables, in order to overcome the legal limit for the marketing imposed by the European Community (Reg. $n^{\circ} 1258 / 2011$ ).

With the aim to boost yield and to contain the risk of nitrate accumulation in the leaves, the research community is focusing on the use of sustainable production technologies, including application of beneficial microorganisms (Plant growth promoting Rhizobacteria, mycorrhiza and Trichoderma) and plant biostimulants [3-6]. In function of their origin, non-microbial plant biostimulants can be classified into five categories: (i) Seaweed extracts and microalgae, (ii) protein hydrolysate $(\mathrm{PH})$ and amino acid containing products, (iii) plant extracts, (iv) humic substances and (v) silicon, with the first three groups commanding $75 \%$ of the market share [7-10]. Protein hydrolysate and amino acids containing products are normally obtained by enzymatic and/or chemical hydrolysis depending on the organic matrix (animal or vegetal) and are characterized by high percentages of amino acids and peptides, followed by carbohydrates and small amounts of micronutrients $[7,8]$. Moreover, plant extracts are normally produced through the fermentation of tropical plants and contain amino acids and peptides, carbohydrates but also vitamins and micronutrients with small quantities of phytohormones [8], while seaweed extracts particularly the brown macroalgae are obtained through a process called 'cold cell burst' and contain polysaccharides, osmolytes (proline and betaines), macro- and micro-nutrients, brassinosteroids and phytohormones (auxins, cytokinins and gibberellins; [11,12]).

Recent studies carried out on vegetable crops including leafy greens have demonstrated that foliar and/or root applications of plant or seaweed-based biostimulants elicit several physiological and molecular processes, thus resulting in improvements in growth, productivity, nutritional quality and nutrient use efficiency (NUE) and tolerance to abiotic stressors such as drought, soil and water salinity, nutrient deprivation and extreme temperatures [12-24]. The beneficial effects of vegetal- and seaweed-based biostimulants have been attributed to direct and indirect stimulation mechanisms [9]. The direct stimulation action of biostimulants include: (i) Activity enhancement of key enzymes involved in carbon and nitrogen $(\mathrm{N})$ metabolism $[13,20,25]$, (ii) eliciting hormone-activity in particular auxinand gibberellin-like activities through bioactive peptides [26-28], (iii) physiological, biochemical and anatomical changes such as the production of antioxidant enzymes, pigments, secondary metabolites and smallest cell guard length and width $[7,8,12,29]$. In addition to direct mechanisms, indirect modes of actions on agronomical performance and nutrient uptake and assimilation have been also reported when vegetal- or seaweed extract-based biostimulants were applied as substrate drench and/or foliar spray $[8,29]$. The better nutritional status in biostimulant-treated plants in comparison to untreated plants has been mostly associated with root system modulation (increases in root biomass, root length and diameter and lateral root branching $[8,12,29])$.

Among the different agronomical claims of plant biostimulants, the capacity to improve NUE in particular, $\mathrm{N}$ is one of the most important claims supporting their placement in the market for both economic and environmental reasons [9]. However, limited scientific literature are available regarding the effects of plant biostimulants on vegetable crops under sub-optimal $\mathrm{N}$ regimens [20,22,30-32]. For instance, Sestili and co-workers [20] demonstrated that the application of a PH at optimal and sub-optimal $\mathrm{N}$ regimens enhanced hydroponically grown tomato performance, especially substrate drench. Interestingly, the same authors observed that protein hydrolysate at low $\mathrm{N}$ conditions upregulated gene expression for amino acid transporter and glutamine synthetase, leading to a higher assimilation of $\mathrm{N}$ with a positive impact on plant growth. Similarly, Carillo et al. [22] reported that foliar application of $\mathrm{PH}$, especially under suboptimal $\mathrm{N}$ fertilization regimes $\left(0\right.$ or $\left.15 \mathrm{~kg} \mathrm{~N} \mathrm{ha}^{-1}\right)$ boost marketable yield of greenhouse spinach due to an enhancement of nutrient acquisition and to an 
increase in total amino acids in plants as well as to an improvement of photochemical efficiency, thus boosting yield.

Since there is ample evidence of species-specific response to plant biostimulants, especially that of leaf biostimulant permeability (through leaf cuticule and stomatal aperture) and thus the efficacy of the biostimulant product is species-dependent [9]; there is an urgent need among researchers to assess the effect of vegetal- and seaweed based-biostimulants on baby lettuce performance at different $\mathrm{N}$ fertilization regimes.

Taking into account all the previous considerations, an experiment was conducted in a plastic tunnel to assess the response of baby lettuce crop to the foliar application of the legume-derived $\mathrm{PH}$ 'Trainer ${ }^{\circledR}$ ', tropical plant extract 'Auxym ${ }^{\circledR}$ ' and seaweed extract from Ecklonia maxima 'Kelpak ${ }^{\circledR}$ ' under different $\mathrm{N}$ rates of $0,10,20$ and $30 \mathrm{~kg} \mathrm{~N} \cdot \mathrm{ha}^{-1}$. The responses of baby lettuce plants were assessed in terms of yield, leaf morphometric parameters and leaf quality traits.

\section{Materials and Methods}

\subsection{Experimental Setting, Plant Material and Design}

The experiment was carried out in a unheated plastic tunnel covered by polyethylene during the winter 2018 growing season (January 16-March 12) at Gussone Park, experimental site of the Department of Agricultural Sciences $\left(40^{\circ} 48.870^{\prime} \mathrm{N} ; 14^{\circ} 20.821^{\prime} \mathrm{E} ; 70 \mathrm{~m}\right.$ above sea level) located in Portici, southern Italy. The trend of daily maximum and minimum air temperature inside the plastic tunnel is reported in Figure 1. The baby leaf lettuce (Lactuca sativa L.) cv. 'Zarina' (ISI Sementi SpA, Parma, Italy) was used as the selected crop.

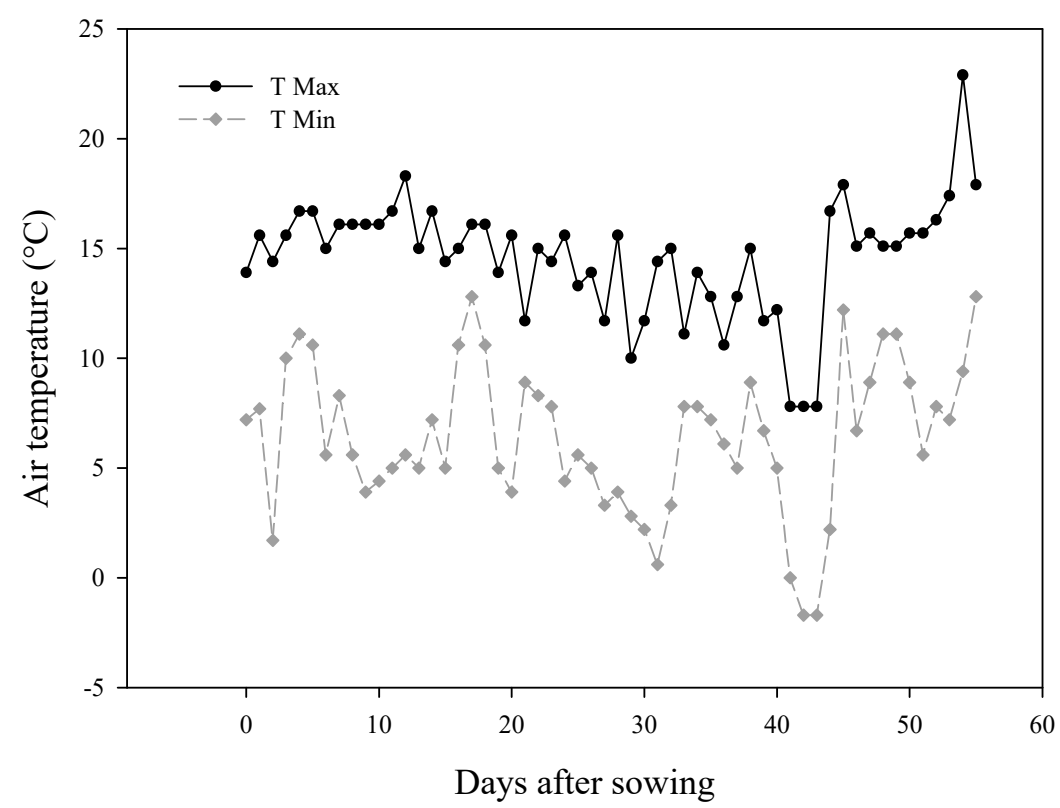

Figure 1. Trend of the maximum and minimum air temperature inside the plastic tunnel during the growing period of baby lettuce.

A factorial combination of $\mathrm{N}$ fertilization $(\mathrm{N})$ and biostimulant application (B) was applied based on four increasing $\mathrm{N}$ fertilization levels $\left(0,10,20\right.$ or $30 \mathrm{~kg} \mathrm{~N} \cdot \mathrm{ha}^{-1}$; N0, N10, N20 and N30, respectively) and three plant biostimulants (seaweed extract—SwE, legume-derived protein hydrolysate-LDPH and tropical plant extract-TPE) and a non-treated control. The experimental design was a randomized complete-block design with three replications, yielding 48 experimental units $(4 \mathrm{~N} \times 4 \mathrm{~B} \times 3$ replications) established in large lysimeters of reinforced fiber glass with a diameter of $0.70 \mathrm{~m}$ and a depth of $0.60 \mathrm{~m}$. 
Each experimental unit consisted of one large lysimeters. The lysimeters were filled with a soil having the following chemical and physical characteristics reported in Table 1.

Table 1. Physical and chemical properties of the soil used in this work.

\begin{tabular}{ccc}
\hline Soil Properties & Units & Mean Values \\
\hline Texture & & \\
Coarse sand & $\%$ & 69.1 \\
Fine sand & $\%$ & 21.9 \\
Silt & $\%$ & 4.5 \\
Clay & $\%$ & 4.5 \\
pH & & \\
Chemical properties & - & 6.54 \\
Electrical conductivity & $\mathrm{dS} \cdot \mathrm{m}^{-1}$ & 0.64 \\
Organic matter & $\mathrm{g} \cdot \mathrm{kg}^{-1}$ & 32.4 \\
Total N (Kjeldahl method) & $\mathrm{g} \cdot \mathrm{kg}^{-1}$ & 1.2 \\
$\mathrm{P}_{2} \mathrm{O}_{5}$ (Olsen method) & $\mathrm{mg} \cdot \mathrm{kg}^{-1}$ & 312.8 \\
$\mathrm{~K}_{2} \mathrm{O}$ (Tetraphenylborate method) & $\mathrm{mg} \cdot \mathrm{kg}^{-1}$ & 620.7 \\
$\mathrm{NO}_{3}-\mathrm{N}$ & $\mathrm{mg} \cdot \mathrm{kg}^{-1}$ & 10.0 \\
$\mathrm{NH}_{4}-\mathrm{N}$ & $\mathrm{mg} \cdot \mathrm{kg}^{-1}$ & 9.0 \\
\hline & &
\end{tabular}

\subsection{Nitrogen Fertilization Levels, Cultural Practices and Biostimulants Application}

The baby leaf lettuce was hand seeded on January 16 at a plant density of 2500 seeds $\cdot \mathrm{m}^{-2}$. The $\mathrm{N}$ was applied as calcium nitrate (26\%) in a single operation 14 days after sowing. The calcium nitrate was used based on standard commercial practices used in Italy.

The three commercial SwE, LDPH and TPE-based biostimulants were made by 'Kelpak ${ }^{\circledR}$ ' $\left(K^{2}\right.$ elp Products (Pty) Ltd., Cape Town, South Africa), 'Trainer ${ }^{\circledR \prime}$ and 'Auxym ${ }^{\circledR}$ ' (Italpollina S.p.A., Rivoli Veronese, Italy), respectively.

The SwE obtained through 'cold cell burst' mainly contained phytohormones (auxins and cytokinins with a very high auxin-to-cytokinin ratio), carbohydrates, amino acids, vitamins (B1, B2, C and E) and macro- and micro-nutrients $[18,19]$. The LDPH-based biostimulant contained free amino acids and peptides $(75 \%)$, carbohydrates $(22 \%)$ and mineral nutrients $(3 \%)$. The detailed aminogram was reported by Paul et al. [33,34]. The TPE biostimulant obtained by fermentation of tropical plants contained $54 \%$ of free amino acids and peptide, $17 \%$ carbohydrate, $23 \%$ mineral nutrients, $6 \%$ vitamins and $0.22 \%$ phytohormones as reported in detail by Caruso et al. [23,24]. Baby lettuce leaf plants were sprayed with a biostimulant solution containing $3 \mathrm{~mL} \cdot \mathrm{L}^{-1}$ of SwE and LDPH and $2 \cdot \mathrm{mL} \mathrm{L}^{-1}$ for TPE-based biostimulant, or with water (non-treated control), five times during the growing season at 7-day intervals, starting three weeks after sowing. The relative doses of the three commercial plant biostimulants were used based on manufacturer recommendations. The volume of the solution used during the five foliar applications was $100 \mathrm{~mL}$ per square meter.

\subsection{Plant Growth Parameters, Marketable Yield, Leaf Colorimetry and Sampling}

On March 12, the baby leaf lettuce was harvested in all experimental units. The leaf area was measured using an electronic leaf area meter (Li-Cor3000, Li-Cor, Lincoln, NE, USA) in order to calculate the leaf area index (LAI). The marketable fresh yield was also measured and expressed in tons per ha, and a sub-sample was oven dried at $70^{\circ} \mathrm{C}$ for 3 days in order to determine the leaf dry matter percentage, and the dry samples were consequently used for the mineral analysis. Furthermore, the specific leaf weight (leaf dry weight per unit area; $\mathrm{mg} \cdot \mathrm{cm}^{-2}$ ) as well as leaf succulence (leaf water content per unit area; $\mathrm{mg} \cdot \mathrm{cm}^{-2}$ ) were also recorded.

Leaf colorimetry was measured on the upper side of 10 leaves per experimental unit using Minolta CR-300 Chroma Meter (Minolta Camera Co. Ltd., Osaka, Japan) in order to obtain the color space 
parameters $\left(L^{*}, a^{*}\right.$ and $\left.b^{*}\right)$ and a portable chlorophyll meter SPAD-502 (Konica Minolta, Tokyo, Japan) was also used to measure the SPAD (Soil Plant Analysis Development) index.

Batch samples of fresh leaves from each experimental unit were frozen in liquid nitrogen immediately after harvest, lyophilized Christ, Alpha 1-4 (Osterode, Germany) and stored at $-80^{\circ} \mathrm{C}$ until further analysis.

\subsection{Antioxidant Capacity Analysis}

The lipophylic and hydrophilic antioxidant capacities were assessed on extract from freeze-dried baby lettuce leaves $(200 \mathrm{mg}$ ) added with methanol and distilled water, respectively. The antioxidant activity of the lipophilic and hydrophilic extract fractions was measured spectrophotometrically based on the methods of Re et al. [35] and Fogliano et al. [36], respectively. The absorbance of the solutions for lipophilic and hydrophilic extract fractions were measured at 734 and $505 \mathrm{~nm}$, respectively. Lipophylic and hydrophilic antioxidant activities were expressed as mmol of Trolox and mmol ascorbic acid per $100 \mathrm{~g}$ of dry weight (dw) [36].

\subsection{Chlorophyllous Pigments and Nitrate Analysis}

Chlorophyll and carotenoids content of the baby lettuce leaves were also assayed spectrophotometrically after the extraction of the fresh material $(500 \mathrm{mg})$ using pure acetone as described in detail by Lichtentahler and Buschmann [37], whereas the nitrate content was determined based on the method of Sah [38]. The absorbance of the solutions for chlorophyll a and b, carotenoids and nitrate were measured at $662,645,470$ and $550 \mathrm{~nm}$. The chlorophyllous pigments were expressed as $\mathrm{mg} \mathrm{g}^{-1}$ fresh weight $(\mathrm{fw})$, while the nitrate content was expressed as $\mathrm{mg} \mathrm{kg}^{-1} \mathrm{fw}$.

\subsection{Total Ascorbic Acid Analysis}

The total ascorbic acid (expressed as mg ascorbic acid on $100 \mathrm{~g} \mathrm{fw}$ ) was also assessed spectrophotometrically based on the protocol by Kampfenkel et al. [39]. The absorbance of the solution for total ascorbic acid was measured at $525 \mathrm{~nm}$.

\subsection{Statistical Processing}

Morphological and qualitative data were statistically analyzed by a 2-way ANOVA using the SPSS 21 software package for Windows 2007. The means were separated by a Duncan's test (significance level 0.05).

\section{Results and Discussion}

\subsection{Effect of $N$ Fertilization Levels and Biostimulant Application on Yield and Growth}

The results regarding morphological parameters and marketable yield of baby lettuce are reported in Figure 2; Figure 3 and Table 2. For marketable fresh yield and leaf area index (LAI) significant interaction between fertilization (F) and biostimulant application (B) was observed, whereas leaf succulence and specific leaf weight (SLW) were only influenced by the two tested factors with no significant $\mathrm{F} \times \mathrm{B}$ interaction (Figures 2 and 3, and Table 2). The fresh yield of baby lettuce in both biostimulant-treated and untreated plants was positively affected by increasing $\mathrm{N}$ fertilization levels from 0 to $20 \mathrm{~kg} \mathrm{~N} \cdot \mathrm{ha}^{-1}$, reaching a plateau thereafter indicating a luxury $\mathrm{N}$ conditions at $30 \mathrm{~kg} \mathrm{~N} \cdot \mathrm{ha}^{-1}$ (Figure 2). The marketable fresh yield of baby lettuce at N0 was clearly higher by $19 \%$ in biostimulant-treated plants compared untreated plants, with no significant differences between the three plant biostimulants tested (Figure 2). Interestingly, foliar spray with LDPH and especially SwE elicited significant increases (average $14 \%, 6 \%$ and $7 \%$ at 10,20 and $30 \mathrm{~kg} \mathrm{~N} \cdot \mathrm{ha}^{-1}$, respectively) compared to TPE and untreated plants (Figure 2). Similarly to the effects on marketable fresh yield, the leaf area index (LAI) in SwE and LDPH-treated plants at 10, 20 and $30 \mathrm{~kg} \mathrm{~N} \cdot \mathrm{ha}^{-1}$ was significantly higher compared to baby lettuce treated with TPE or untreated plants, whereas under non-fertilized 
conditions LAI was significantly higher in biostimulant compared to untreated plants, irrespective of the commercial biostimulants used (Figure 3).

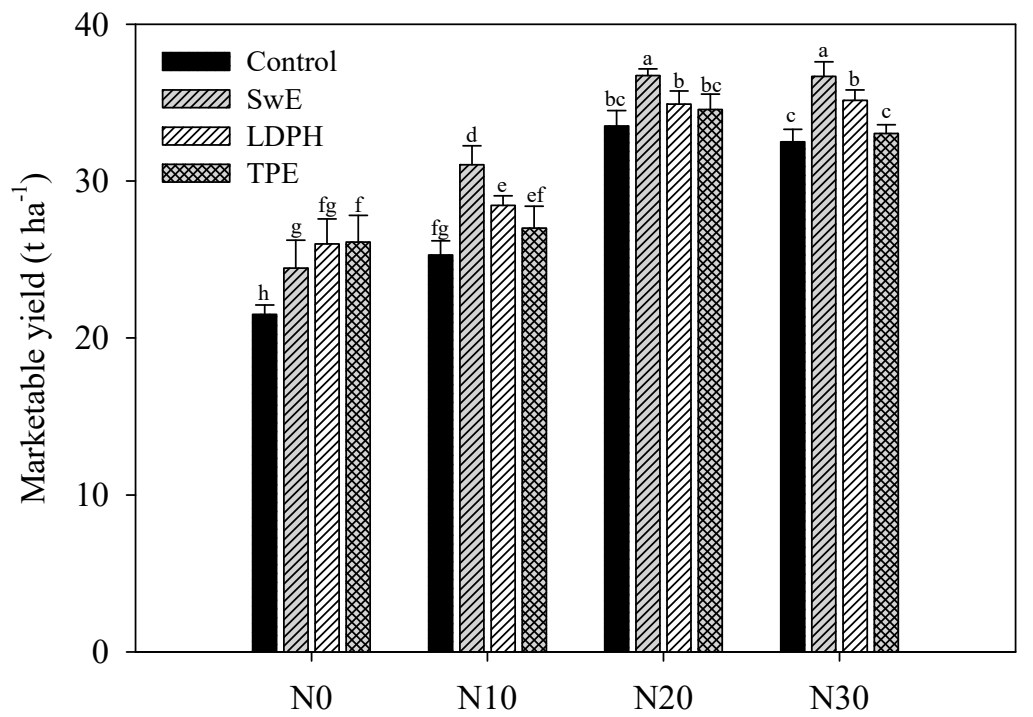

Figure 2. Effects of nitrogen $(\mathrm{N})$ fertilization levels $\left(0,10,20\right.$ and $30 \mathrm{~kg} \mathrm{~N} \cdot \mathrm{ha}^{-1} ; \mathrm{N} 0, \mathrm{~N} 10, \mathrm{~N} 20$ and $\mathrm{N} 30$, respectively) and biostimulant applications (untreated control, SwE: Extract of seaweed Ecklonia maxima, LDPH: Legume-derived protein hydrolysate and TPE: Tropical plant extract) on the marketable fresh yield of baby lettuce plants. Different letters indicate significant differences according to the Duncan's test (significance level 0.05).

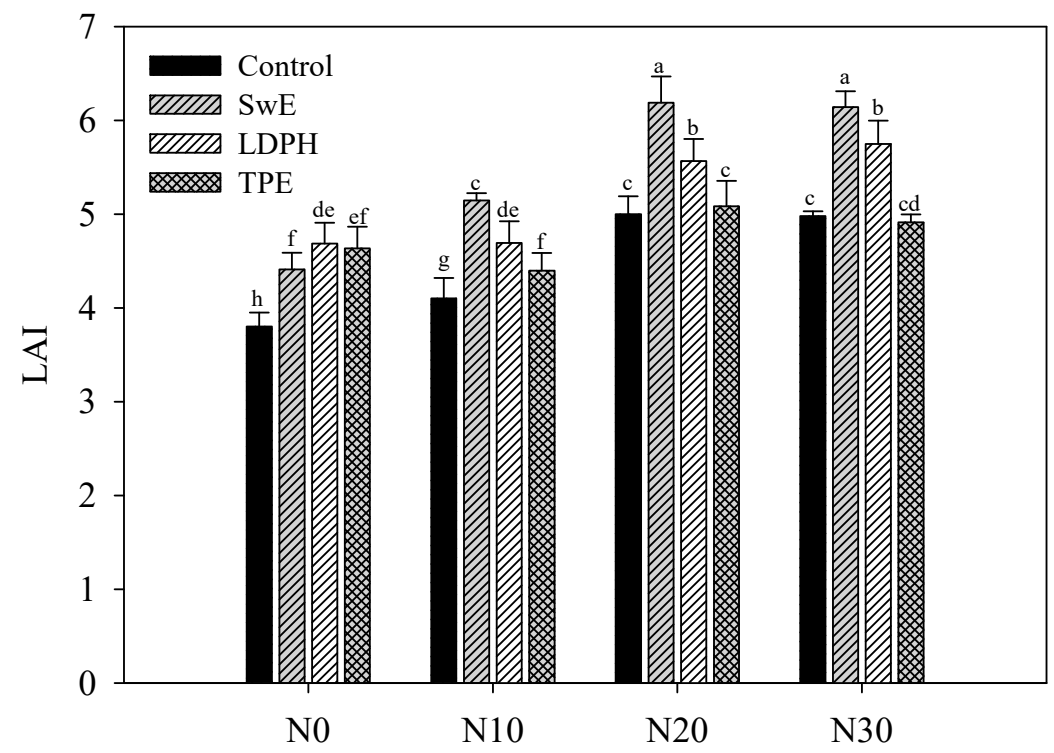

Figure 3. Effects of nitrogen (N) fertilization levels $\left(0,10,20\right.$ and $30 \mathrm{~kg} \mathrm{~N} \cdot \mathrm{ha}^{-1}$; N0, N10, N20 and N30, respectively) and biostimulant applications (untreated control, SwE: Extract of seaweed Ecklonia maxima, LDPH: Legume-derived protein hydrolysate and TPE: Tropical plant extract) on the leaf area index (LAI) of baby lettuce plants. Different letters indicate significant differences according to the Duncan's test (significance level 0.05). 
Table 2. Effects of nitrogen (N) fertilization levels (0, 10, 20 and $30 \mathrm{~kg} \mathrm{~N} \cdot \mathrm{ha}^{-1}$; N0, N10, N20 and N30, respectively) and biostimulant applications (untreated control, SwE: Extract of seaweed Ecklonia maxima, LDPH: Legume-derived protein hydrolysate and TPE: Tropical plant extract) on leaf succulence and specific leaf weight (SLW) of baby lettuce plants.

\begin{tabular}{ccc}
\hline Treatments & Succulence & SLW \\
\hline Fertilization (F) & $\left(\mathrm{mg} \mathrm{H}_{2} \mathrm{O} \cdot \mathrm{cm}^{-2}\right)$ & $\left(\mathrm{mg} \mathrm{dm} \cdot \mathrm{cm}^{-2}\right)$ \\
N0 & $59.9 \mathrm{~b}$ & \\
N10 & $71.5 \mathrm{a}$ & $2.99 \mathrm{a}$ \\
N20 & $69.9 \mathrm{a}$ & $3.26 \mathrm{a}$ \\
N30 & $67.7 \mathrm{a}$ & $2.66 \mathrm{~b}$ \\
Biostimulant (B) & $60.5 \mathrm{c}$ & $2.60 \mathrm{~b}$ \\
Control & $65.2 \mathrm{~b}$ & $2.94 \mathrm{a}$ \\
SwE & $70.4 \mathrm{a}$ & $2.56 \mathrm{~b}$ \\
LDPH & $72.9 \mathrm{a}$ & $2.92 \mathrm{a}$ \\
TPE & $* *$ & $3.10 \mathrm{a}$ \\
Significance & $*$ & $* *$ \\
F & NS & $*$ \\
B & NS \\
F $\times$ B & & \\
\hline
\end{tabular}

$\mathrm{NS},{ }^{*}$, and ${ }^{* *}$ indicate non-significant, significant at $p<0.05$, significant at $p<0.01$, respectively. Different letters indicate significant differences according to the Duncan's test (significance level 0.05).

When averaged over biostimulant application $(\mathrm{F} \times \mathrm{B}=$ not significant), the leaf succulence increased quadratically by increasing $\mathrm{N}$ fertilization levels from 10 to $30 \mathrm{~kg} \mathrm{~N} \cdot \mathrm{ha}^{-1}$ with no significant difference among the three $\mathrm{N}$ fertilization rates, whereas the SLW declined at 20 and $30 \mathrm{~kg} \mathrm{~N} \cdot \mathrm{ha}^{-1}$ (Table 2). Averaged over $\mathrm{N}$ fertilization levels, significant differentiation in terms of leaf succulence and SLW was recorded in response to biostimulants application with the higher values of succulence observed with LDPH and TPE followed by SwE as opposed to untreated plants, whereas the lowest values of SLW were recorded in baby lettuce treated with Ecklonia maxima extract (Table 2).

The stimulation effect of commercial biostimulants $(6 \%-19 \%)$ recorded in the current research is in line with previous studies carried out on greenhouse fresh tomato treated with seaweed extracts of $E$. maxima or Ascophyllum nodosum, LDPE and TPE (7\%-25\%; [12,40]) but far lower than those recorded on greenhouse spinach [19]. The different stimulation effect among tested species indicates a crop-specific differential response to plant biostimulant applications and thus requires additional crop-specific studies to optimize plant biostimulants application, taking into consideration the following factors: environment, management practice and plant morphological traits (e.g., leaf permeability and cuticle thickness $[9,28])$.

Interestingly, LDPH (at $0 \mathrm{~kg} \mathrm{~N} \cdot h \mathrm{~h}^{-1}$ ) and SwE (at 10, 20 and $30 \mathrm{~kg} \mathrm{~N} \cdot \mathrm{ha}^{-1}$ ) are likely to boost growth response and crop productivity as a consequence of the presence of bioactive molecules such as amino acids (tryptophan, glutamic and aspartic acids), soluble peptides (in LDPH) and polysaccharides (laminarans, fucoidans and alginates), phenolic compounds, osmolytes (proline, betaine and manitol) and phyohormones (abscisic acid, auxins, brassinosteroids, cytokinins and gibberellins) (in SwE) $[8,29]$. These former molecules present in seaweed and PH-based biostimulants may have triggered a signal transduction pathway through elicitation of endogenous phytohormone synthesis, thus leading to a higher crop productivity compared to untreated-baby lettuce plants $[19,20]$. Another possible mechanism of action (indirect mechanism) behind the stimulation of LAI and marketable fresh yield could be the modulation of the root system architecture in terms of root biomass, root volume and length and higher root branching triggered by tryptophan in LDPH and auxins in SwE, which improved nutrient uptake/translocation/assimilation, leading to a higher agronomical performance [12,19,41,42]. Our results are in agreement with those of Carillo and co-workers [22] who reported that foliar application of LDPH at a rate of $4 \mathrm{~mL} \cdot \mathrm{L}^{-1}$ under suboptimal $\mathrm{N}$ fertilization 
conditions ( 0 and $\left.15 \mathrm{~kg} \mathrm{~N} \cdot \mathrm{ha}^{-1}\right)$ increased the fresh yield of greenhouse spinach through an increase of the nutritional status (higher macronutrient accumulation), better photosynthetic activity and improving the total acid content.

\subsection{Effect of N Fertilization Levels and Biostimulant Application on Leaf Colorimetry and SPAD Index}

Among the physical properties that may affect the purchasing decisions of vegetable consumers is product appearance, in particular, the color of the vegetable [43]. In the present study, no significant interaction between $\mathrm{N}$ fertilization and biostimulants application was recorded for the three leaf colorimetric parameters lightness $\left(L^{*}\right)$, green color intensity (negative values of $a^{*}$ ) and yellow color intensity (positive values of $b^{*}$ ) (Table 3 ). The colorimetric CIELAB components $L^{*}$ and $b^{*}$ were significantly influenced by the two tested factors, whereas $a^{*}$ was only affected by $\mathrm{N}$ fertilization levels (Table 3). Increasing the $\mathrm{N}$ fertilization levels from 0 to $30 \mathrm{~kg} \mathrm{~N} \cdot \mathrm{ha}^{-1}$ yielded lighter baby lettuce leaf expression by increasing $L^{*}$ values, but with a decrease in $a^{*}$ values (Table 3 ). Moreover, when averaged over $\mathrm{N}$ fertilization levels, the foliar application of SwE and TPE-based biostimulants elicited an increase in $L^{*}$ values compared to the untreated control, whereas LDPH treatment exhibited intermediate values (Table 3 ).

Table 3. Effects of nitrogen (N) fertilization levels $\left(0,10,20\right.$ and $30 \mathrm{~kg} \mathrm{~N} \cdot \mathrm{ha}^{-1}$; N0, N10, N20 and $\mathrm{N} 30$, respectively) and biostimulant applications (untreated control, SwE: Extract of seaweed Ecklonia maxima, LDPH: Legume-derived protein hydrolysate and TPE: Tropical plant extract) on leaf hunter color parameters of baby lettuce plants.

\begin{tabular}{cccc}
\hline Table & $\boldsymbol{L}^{*}$ & $\boldsymbol{a}^{*}$ & $\boldsymbol{b}^{*}$ \\
\hline Fertilization (F) & & & \\
N0 & $55.9 \mathrm{~d}$ & $-20.8 \mathrm{a}$ & $39.8 \mathrm{~b}$ \\
N10 & $56.7 \mathrm{c}$ & $-21.2 \mathrm{a}$ & $40.1 \mathrm{~b}$ \\
N20 & $58.7 \mathrm{~b}$ & $-22.7 \mathrm{~b}$ & $41.8 \mathrm{a}$ \\
N30 & $59.5 \mathrm{a}$ & $-22.7 \mathrm{~b}$ & $42.4 \mathrm{a}$ \\
Biostimulants (B) & & & \\
Control & $56.5 \mathrm{c}$ & -21.5 & $39.8 \mathrm{~b}$ \\
SwE & $58.5 \mathrm{a}$ & -22.2 & $41.6 \mathrm{a}$ \\
LDPH & $57.5 \mathrm{~b}$ & -21.8 & $41.0 \mathrm{a}$ \\
TPE & $58.3 \mathrm{a}$ & -21.9 & $41.6 \mathrm{a}$ \\
Significance & & & \\
F & $* *$ & $*$ & $*$ \\
B & $*$ & NS & NS \\
F $\times$ B & NS & NS & NS
\end{tabular}

NS, ${ }^{*}$, and ${ }^{* *}$ indicate non-significant, significant at $p<0.05$, or significant at $p<0.01$, respectively. Different letters indicate significant differences according to the Duncan's test (significance level 0.05).

Interestingly, the foliar application of commercial plant biostimulants improved the SPAD index significantly; this is an important physiological parameter having a crucial role on the primary metabolism of plants. With the exception of under N20, where no significant difference in the SPAD index was observed, between biostimulants-treated and untreated plants, the foliar application with SwE (at 10 and $30 \mathrm{~kg} \mathrm{~N} \cdot \mathrm{ha}^{-1}$ ) and with the three commercial biostimulants (at $0 \mathrm{~kg} \mathrm{~N} \cdot \mathrm{ha}^{-1}$ ) incurred a significant increase in the SPAD index (Figure 4). Our findings have been also demonstrated in many leafy vegetable species such as jute, lettuce, and spinach $[16,19,22]$. The highest SPAD values observed after the application of plant biostimulants in particular extracts from brown macroalgae could be attributed to several putative mechanisms like the following: (i) better translocation of soluble sugars via the phloem, (ii) increases in the biogenesis of chloroplast, as well as (iii) limited chlorophyll degradation, and thus, delayed senescence $[29,44,45]$. 


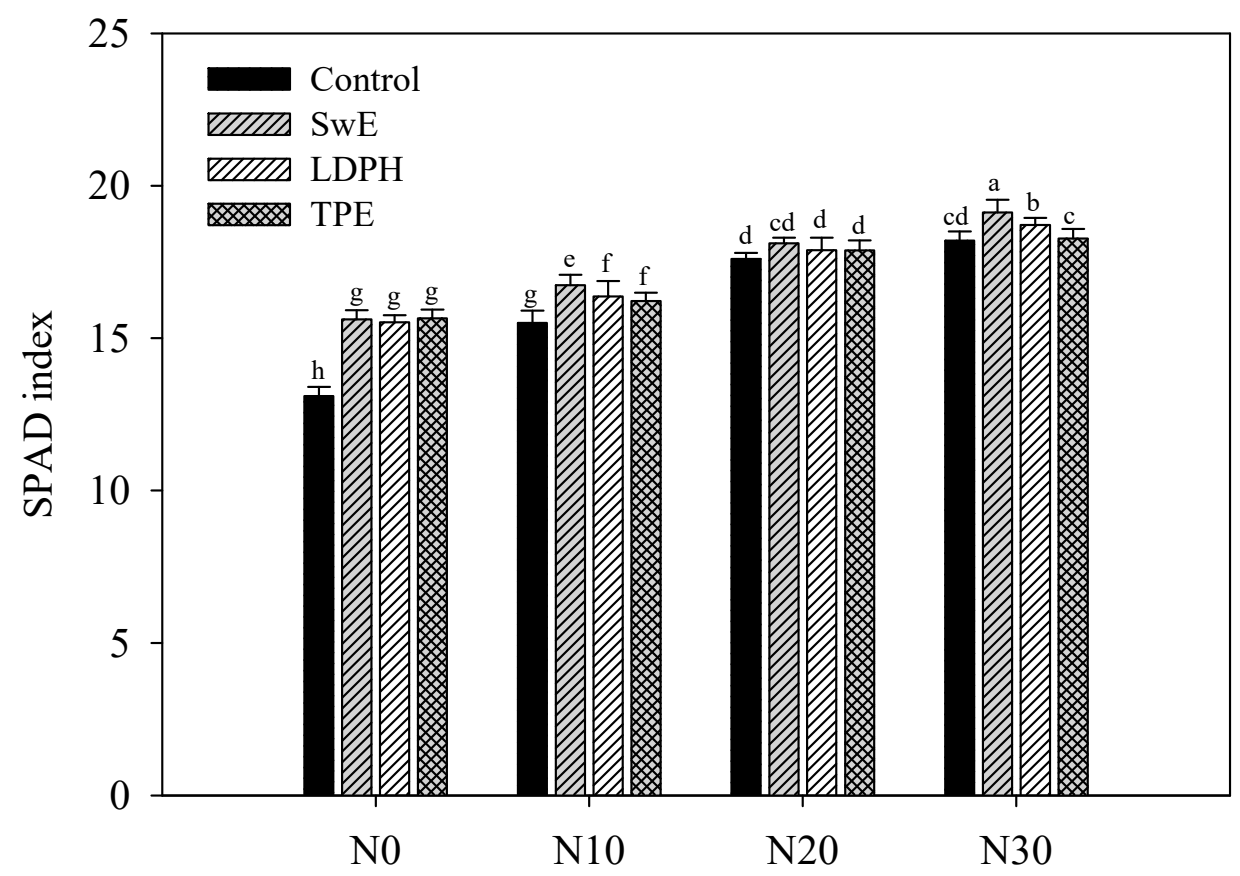

Figure 4. Effects of nitrogen (N) fertilization levels (0, 10, 20 and $30 \mathrm{~kg} \mathrm{~N} \cdot \mathrm{ha}^{-1}$; N0, N10, N20 and $\mathrm{N} 30$, respectively) and biostimulant applications (untreated control, SwE: Extract of seaweed Ecklonia maxima, LDPH: Legume-derived protein hydrolysate and TPE: Tropical plant extract) on the SPAD index of baby lettuce plants. Different letters indicate significant differences according to the Duncan's test (significance level 0.05).

\subsection{Effect of N Fertilization Levels and Biostimulant Application on Nitrate Accumulation and Biochemical Parameters}

Nitrate was affected by both $\mathrm{N}$ fertilization levels and biostimulant application, without significant $\mathrm{F} \times \mathrm{B}$ interaction (Table 4). The nitrate concentration in baby lettuce leaf was negatively affected by $\mathrm{N}$ fertilization levels. Increasing the $\mathrm{N}$ fertilization from 0 to $30 \mathrm{~kg} \mathrm{~N} \cdot \mathrm{ha}^{-1}$ increased the nitrate accumulation in leaves, especially at 20 and $30 \mathrm{~kg} \mathrm{~N} \cdot \mathrm{ha}^{-1}$, where the content of nitrate was above the upper limits set by the European Union (EU) for safe lettuce marketing (Commission Regulation No. $1258 / 2011 ; 3000$ to $5000 \mathrm{mg} \mathrm{NO}{ }_{3}^{-} \cdot \mathrm{kg}^{-1}$ of lettuce depending on growing season and cultivation conditions). On the other hand, when averaged over $\mathrm{N}$ fertilization levels, the nitrate concentration in LDPH treated plants was significantly lower on average by $21.2 \%$ compared to baby lettuce treated with SwE or TPE and it was not significantly different than untreated-baby lettuce plants (Table 4). The capacity of LDPH, which is mainly composed of soluble solids and especially amino acids, to accumulate less nitrate in the leaf tissue, could be attributed to a molecular mechanism such as the up-regulation of genes involved in $\mathrm{N}$ metabolism such as nitrate reducatse, and consequently, to an augmenting assimilation of nitrates into amino acids [46,47]. Furthermore, other studies conducted by Sady and Smoleń [31] and Smoleń and Sady [32] on carrots and spinach, respectively, reported that after the foliar application of 'Pentakeep V' containing 5-aminolevulinic acid was able to reduce nitrate accumulation in combination with a $50 \% \mathrm{~N}$ dose, whereas an opposite trend was observed in combination with $100 \% \mathrm{~N}$. The authors concluded that nitrate accumulation in response to biostimulant application may change in relation to several interacting variables including species, variety and $\mathrm{N}$ application rates. 
Table 4. Effects of nitrogen (N) fertilization levels (0, 10, 20 and $30 \mathrm{~kg} \mathrm{~N} \cdot \mathrm{ha}^{-1}$; N0, N10, N20 and N30, respectively) and biostimulant applications (untreated control, SwE: Extract of seaweed Ecklonia maxima, LDPH: Legume-derived protein hydrolysate and TPE: Tropical plant extract) on nitrate, chlorophyll and carotenoids content of baby lettuce plants.

\begin{tabular}{|c|c|c|c|c|c|}
\hline Treatments & Nitrate & Chlorophyll a & Chlorophyll b & $\begin{array}{c}\text { Total } \\
\text { chlorophyll }\end{array}$ & Carotenoids \\
\hline & $\left(\mathrm{mg} \cdot \mathrm{kg}^{-1} \mathrm{fw}\right)$ & $\left(m g \cdot g^{-1} f w\right)$ & $\left(m g \cdot g^{-1} f w\right)$ & $\left(\mathrm{mg} \cdot \mathrm{g}^{-1} \mathrm{fw}\right)$ & $\left(\mu \mathrm{g} \cdot \mathrm{g}^{-1} \mathrm{fw}\right)$ \\
\hline \multicolumn{6}{|l|}{ Fertilization (F) } \\
\hline No & $703.3 \mathrm{~d}$ & $0.298 \mathrm{~b}$ & 0.211 & $0.508 \mathrm{~b}$ & $156 \mathrm{~b}$ \\
\hline N10 & $1476.0 \mathrm{c}$ & $0.330 \mathrm{a}$ & 0.210 & $0.540 \mathrm{a}$ & 178 a \\
\hline N20 & $6206.7 \mathrm{~b}$ & $0.334 \mathrm{a}$ & 0.201 & $0.535 \mathrm{a}$ & $170 \mathrm{a}$ \\
\hline N30 & 7288.1 a & $0.338 \mathrm{a}$ & 0.209 & $0.546 \mathrm{a}$ & 170 a \\
\hline \multicolumn{6}{|l|}{ Biostimulants (B) } \\
\hline Control & $3366.5 \mathrm{~b}$ & $0.302 \mathrm{~b}$ & $0.191 \mathrm{c}$ & $0.493 \mathrm{~b}$ & $155 \mathrm{c}$ \\
\hline SwE & 4467.6 a & $0.319 \mathrm{~b}$ & $0.192 \mathrm{c}$ & $0.511 \mathrm{~b}$ & $181 \mathrm{a}$ \\
\hline LDPH & $3504.4 \mathrm{~b}$ & $0.342 \mathrm{a}$ & $0.214 \mathrm{~b}$ & $0.556 \mathrm{a}$ & $173 \mathrm{ab}$ \\
\hline TPE & $4426.5 \mathrm{a}$ & $0.337 \mathrm{a}$ & $0.232 \mathrm{a}$ & $0.569 \mathrm{a}$ & $164 \mathrm{bc}$ \\
\hline \multicolumn{6}{|l|}{ Significance } \\
\hline $\mathrm{F}$ & ** & * & NS & * & * \\
\hline B & * & * & $* *$ & * & * \\
\hline $\mathrm{F} \times \mathrm{B}$ & NS & NS & NS & NS & NS \\
\hline
\end{tabular}

$\mathrm{NS}^{*}$, and ${ }^{* *}$ indicate non-significant, significant at $p<0.05$, or significant at $p<0.01$, respectively. Different letters indicate significant differences according to the Duncan's test (significance level 0.05).

One of the beneficial responses of plant biostimulants application is an increase in chlorophyllous pigments such as chlorophyll a, b and total, as well as carotenoids. This was the case in the current research study, since the foliar application of LDPH and TPE incurred a significant increase in chlorophyll $\mathrm{a}$ and $\mathrm{b}$ and consequently the total chlorophyll compared to SwE and untreated-baby lettuce plants (Table 4). Furthermore, the content of carotenoids was positively affected by the foliar application of SwE and LDPH compared to the control treatment (Table 4). This beneficial effect of vegetal and seaweed extract-based biostimulants on carotenoids and especially chlorophyll content has been recorded also in corn, jute and eggplant $[21,22,48,49]$. The increase in chlorophyll a and total content in both LDPH and TPE (characterized by the high percentage of free amino acids $(75 \%$ and $54 \%$, respectively $[23,24]$ ) could be attributed to the higher content of primary amino acids in the vegetal-based treated plants as amino acids (e.g., alanine, aspartate, asparagines and glutamate) which help to boost chlorophyll content, and consequently, increase photosynthetic activity as well as the quantum yield of $\mathrm{O}_{2}$ evolution [22].

\subsection{Effect of N Fertilization Levels and Biostimulant Application on Antioxidant Capacity and Bioactive Content}

Lipophilic (LAA) and hydrophilic (HAA) antioxidant activities as well as total ascorbic acid (TAA) were significantly affected by both factors with a significant $\mathrm{F} \times \mathrm{B}$ interaction (Table 5). Antioxidant scavenging activity was an important functional quality parameter in assessing the nutritional properties of foods including leafy vegetables, since lipophilic (e.g., $\beta$-carotene, lutein, $\alpha$-tocopherol, etc.) and hydrophilic (e.g., vitamin C, caffeic acid, ferulic acid, quercitin, etc.) antioxidant molecules impart beneficial effects to human health, as these bioactive molecules are known to play a primary role in delaying oxidative damage, thus, preventing a wide range of diseases [50-54]. In the current study, LAA, HAA and TAA of the baby lettuce ranged from 19.9 to $32.3 \mathrm{mmol}$ trolox $100 \cdot \mathrm{g}^{-1} \mathrm{dw}$, from 3.0 to $8.2 \mathrm{mmol}$ ascorbic acid $100 \mathrm{~g}^{-1} \mathrm{dw}$ and from 6.8 to $33.4 \mathrm{mg} \mathrm{g}^{-1}$, respectively (Table 5). 
Table 5. Effects of nitrogen (N) fertilization levels $\left(0,10,20\right.$ and $30 \mathrm{~kg} \mathrm{~N} \mathrm{ha}^{-1}$; N0, N10, N20 and N30, respectively) and biostimulant applications (untreated control, SwE: Extract of seaweed Ecklonia maxima, LDPH: Legume-derived protein hydrolysate and TPE: Tropical plant extract) lipophilic (LAA) and hydrophilic (HAA) antioxidant activities and total ascorbic acid (TAA) of baby lettuce plants.

\begin{tabular}{|c|c|c|c|c|}
\hline Treatments & & LAA & HAA & TAA \\
\hline & & $\begin{array}{l}\text { mmol Trolox eq. } \\
100 \mathrm{~g}^{-1} \mathrm{dw}\end{array}$ & $\begin{array}{l}\text { mmol ascorbic acid } \\
\text { eq. } 100 \mathrm{~g}^{-1} \mathrm{dw}\end{array}$ & $\mathrm{mg} \mathrm{g}^{-1} \mathrm{fw}$ \\
\hline \multirow{4}{*}{ No } & Control & $26.2 \mathrm{~b}$ & $6.7 c$ & $25.0 \mathrm{~b}$ \\
\hline & SwE & $27.6 \mathrm{~b}$ & $6.6 \mathrm{c}$ & $33.4 \mathrm{a}$ \\
\hline & LDPH & $32.3 \mathrm{a}$ & $8.2 \mathrm{a}$ & $18.0 \mathrm{c}$ \\
\hline & TPE & $25.2 \mathrm{~b}$ & $7.2 \mathrm{bc}$ & $18.6 \mathrm{c}$ \\
\hline \multirow{4}{*}{ N10 } & Control & $21.0 \mathrm{c}$ & $7.6 \mathrm{~b}$ & $17.3 \mathrm{c}$ \\
\hline & SwE & $20.4 \mathrm{c}$ & $7.5 \mathrm{~b}$ & $16.8 \mathrm{c}$ \\
\hline & LDPH & $20.9 c$ & $7.7 \mathrm{~b}$ & $18.1 \mathrm{c}$ \\
\hline & TPE & $30.9 \mathrm{a}$ & $7.6 \mathrm{~b}$ & $16.9 \mathrm{c}$ \\
\hline \multirow{4}{*}{ N20 } & Control & $22.0 \mathrm{c}$ & $4.9 \mathrm{~d}$ & $14.0 \mathrm{de}$ \\
\hline & SwE & $22.2 \mathrm{c}$ & $4.8 \mathrm{~d}$ & $14.3 \mathrm{~d}$ \\
\hline & LDPH & $19.9 \mathrm{c}$ & $4.4 \mathrm{~d}$ & $12.6 \mathrm{de}$ \\
\hline & TPE & $22.1 \mathrm{c}$ & $3.0 \mathrm{e}$ & $14.5 \mathrm{~d}$ \\
\hline \multirow{4}{*}{ N30 } & Control & $21.8 \mathrm{c}$ & $3.3 \mathrm{e}$ & $13.2 \mathrm{de}$ \\
\hline & SwE & $20.1 \mathrm{c}$ & $3.2 \mathrm{e}$ & $11.7 \mathrm{e}$ \\
\hline & LDPH & $21.9 c$ & $4.5 \mathrm{~d}$ & $12.6 \mathrm{de}$ \\
\hline & TPE & $21.5 c$ & $3.4 \mathrm{e}$ & $6.8 \mathrm{f}$ \\
\hline Significance & & & & \\
\hline Fertilization $(\mathrm{F})$ & & $* *$ & $* *$ & $* *$ \\
\hline Biostimulant (B) & & * & * & $* *$ \\
\hline $\mathrm{F} \times \mathrm{B}$ & & $* *$ & $* *$ & $* *$ \\
\hline
\end{tabular}

$*{ }^{* * *}$ significant at $p<0.05$ and 0.01 , respectively. Different letters indicate significant differences according to the Duncan's test (significance level 0.05).

High $\mathrm{N}$ fertilizer application (20 and especially $30 \mathrm{~kg} \cdot \mathrm{N} \mathrm{ha}^{-1}$ ) resulted in undesirable decreases in HAA and TAA of baby lettuce leaves (Table 5), which is in agreement with the results of Wang et al. [55] who reported that high $\mathrm{N}$ fertilization levels can result in undesirable changes in the quality attributes of fruit and leafy vegetables such as soluble solids and ascorbic acid leading to a decrease in commercial, nutritional and functional quality.

The vegetal- and seaweed extract-based biostimulants applied to baby lettuce resulted in higher antioxidant capacity and bioactive content depending on the $\mathrm{N}$ fertilization levels compared to untreated control treatment. For instance, at N0 the highest antioxidant activities and TAA compared to the untreated control were recorded in baby lettuce treated with LDPH and SwE-based biostimulant plants, respectively, whereas at N10 and N30 the highest LAA and HAA contents were observed in TPE and LDPH treated plants, respectively (Table 5). Our findings on the effect of plant biostimulants on nutritional and functional quality of the product were in line with previous research on vegetal-based biostimulants (protein hydrolysate and plant extract) conducted by Caruso et al. [23], in which foliar application at weekly interval increases the LAA, HAA and TAA contents of perennial wall rocket compared to the non-treated control. Similarly, Vasantharaja et al. [56] demonstrated that the application of seaweed extract-based biostimulant (Sargassum swartzii) boosted the antioxidant activity and the bioactive content (e.g., phenols and vitamin C) of cowpea. A mechanistic explanation of the beneficial effect of plant biostimulants, in particular LDPH, on the biosynthesis of antioxidant molecules could be due to: i) the activity stimulation of key enzymes involved in antioxidant homeostasis in cells, and ii) the higher macro- and micro-nutrient assimilation of biostimulant-treated plants which could contribute to the synthesis of amino acids, phenylalanine and tyrosine $[7,40]$. 


\section{Conclusions}

The idea of working with plant biostimulants to increase yield under both optimal and suboptimal conditions is gaining interest among leafy vegetable growers, as well as private companies and researchers for both economic and environmental reasons. The foliar application of vegetal and seaweed extract-based biostimulants, in particular SwE and LDPH enhanced plant growth, and productivity especially under sub-optimal $\mathrm{N}$ regimens, and to a lesser extent; at 20 and $30 \mathrm{~kg}$ $\mathrm{N} \cdot \mathrm{ha}^{-1}$. The foliar application of SwE and LDPH was effective in supporting better physiological and biochemical status in terms of the SPAD index, chlorophyll and carotenoids content leading to a higher agronomical performance. Interestingly, the leaf quality traits of baby lettuce leaf can be improved by biostimulation action, especially with LDPH which delivered leaves with high antioxidant activity and total ascorbic acid as well as low nitrate content. The results of the current experiment highlight the benefit of using vegetal and seaweed extract-based biostimulants in baby lettuce to improve productivity under both optimal and especially suboptimal $\mathrm{N}$ regimens, bringing benefits to farmers and to the environment.

Author Contributions: Conceptualization, M.M.; methodology, I.D.M., E.C.; software, L.O.; validation, M.M., I.D.M., E.C. and L.O.; formal analysis, L.O.; investigation, I.D.M.; resources, M.M.; data curation, I.D.M. and L.O.; writing — original draft preparation, I.D.M.; writing—review and editing, Y.R.; visualization, M.G. and G.C.; supervision, G.C. and M.M.; project administration, M.M.; funding acquisition, M.M.

Conflicts of Interest: The authors declare no conflicts of interest.

\section{References}

1. Colonna, E.; Rouphael, Y.; Barbieri, G.; De Pascale, S. Nutritional quality of leafy vegetables harvested at two light intensities. Food Chem. 2016, 199, 702-710. [CrossRef] [PubMed]

2. Skovgaard, M.; Renjel Encinas, S.; Jensen, O.C.; Andersen, J.H.; Condarco, G.; Jørs, E. Pesticide residues in commercial lettuce, onion, and potato samples from Bolivia-A threat to public health? Environ. Health Insights 2017, 11, 1-8. [CrossRef] [PubMed]

3. De Pascale, S.; Rouphael, Y.; Colla, G. Plant biostimulants: Innovative tool for enhancing plant nutrition in organic farming. Eur. J. Hortic. Sci. 2017, 82, 277-285. [CrossRef]

4. Rouphael, Y.; Franken, P.; Schneider, C.; Schwarz, D.; Giovannetti, M.; Agnolucci, M.; De Pascale, S.; Bonini, P.; Colla, G. Arbuscular mycorrhizal fungi act as biostimulants in horticultural crops. Sci. Hortic. 2015, 196, 91-108. [CrossRef]

5. Rouphael, Y.; Kyriacou, M.C.; Petropoulos, S.A.; De Pascale, S.; Colla, G. Improving vegetable quality in controlled environments. Sci. Hortic. 2018, 234, 275-289. [CrossRef]

6. Rouphael, Y.; Spíchal, L.; Panzarová, K.; Casa, R.; Colla, G. High-throughput plant phenotyping for developing novel biostimulants: From lab to field or from field to lab? Front. Plant Sci. 2018, 9, 1197. [CrossRef] [PubMed]

7. Colla, G.; Nardi, S.; Cardarelli, M.; Ertani, A.; Lucini, L.; Canaguier, R.; Rouphael, Y. Protein hydrolysates as biostimulants in horticulture. Sci. Hortic. 2015, 196, 28-38. [CrossRef]

8. Colla, G.; Hoagland, L.; Ruzzi, M.; Cardarelli, M.; Bonini, P.; Canaguier, R.; Rouphael, Y. Biostimulant action of protein hydrolysates: Unraveling their effects on plant physiology and microbiome. Front. Plant Sci. 2017, 8, 2202. [CrossRef]

9. Rouphael, Y.; Colla, G. Synergistic biostimulatory action: Designing the next generation of plant biostimulants for sustainable agriculture. Front. Plant Sci. 2018, 9. [CrossRef]

10. Chiaiese, P.; Corrado, G.; Colla, G.; Kyriacou, M.C.; Rouphael, Y. Renewable sources of plant biostimulation: Microalgae as a sustainable means to improve crop performance. Front. Plant Sci. 2018, 9, 1782. [CrossRef]

11. Di Stasio, E.; Rouphael, Y.; Colla, G.; Raimondi, G.; Giordano, M.; Pannico, A.; El-Nakhel, C.; De Pascale, S. The Influence of Ecklonia maxima seaweed extract on growth, photosynthetic activity and mineral composition of Brassica rapa L. subsp. sylvestris under nutrient stress conditions. Eur. J. Hortic. Sci. 2017, 82, $286-293$. [CrossRef] 
12. Rouphael, Y.; De Micco, V.; Arena, C.; Raimondi, G.; Colla, G.; De Pascale, S. Effect of Ecklonia maxima seaweed extract on yield, mineral composition, gas exchange and leaf anatomy of zucchini squash grown under saline conditions. J. Appl. Phycol. 2017, 29, 459-470. [CrossRef]

13. Ertani, A.; Cavani, L.; Pizzeghello, D.; Brandellero, E.; Altissimo, A.; Ciavatta, C.; Nardi, S. Biostimulant activity of two protein hydrolyzates in the growth and nitrogen metabolism of maize seedlings. J. Plant Nutr. Soil Sci. 2009, 172, 237-244. [CrossRef]

14. Ertani, A.; Schiavon, M.; Muscolo, A.; Nardi, S. Alfalfa plant-derived biostimulant stimulate short-term growth of salt stressed Zea mays L. plants. Plant Soil 2013, 64, 145-158. [CrossRef]

15. Botta, A. Enhancing plant tolerance to temperature stress with amino acids: An approach to their mode of action. Acta Hortic. 2013, 1009, 29-35. [CrossRef]

16. Lucini, L.; Rouphael, Y.; Cardarelli, M.; Canaguier, R.; Kumar, P.; Colla, G. The effect of a plant-derived biostimulant on metabolic profiling and crop performance of lettuce grown under saline conditions. Sci. Hortic. 2015, 182, 124-133. [CrossRef]

17. Lucini, L.; Rouphael, Y.; Cardarelli, M.; Bonini, P.; Baffi, C.; Colla, G. A vegetal biopolymer-based biostimulant promoted root growth in melon while triggering brassinosteroids and stress-related compounds. Front. Plant Sci. 2018, 9, 472. [CrossRef]

18. Rouphael, Y.; Colla, G.; Giordano, M.; El-Nakhel, C.; Kyriacou, M.C.; De Pascale, S. Foliar applications of a legume-derived protein hydrolysate elicit dose dependent increases of growth, leaf mineral composition, yield and fruit quality in two greenhouse tomato cultivars. Sci. Hortic. 2017, 226, 353-360. [CrossRef]

19. Rouphael, Y.; Giordano, M.; Cardarelli, M.; Cozzolino, E.; Mori, M.; Kyriacou, M.; Bonini, P.; Colla, G. Plant and seaweed-based extracts increase yield but differentially modulate nutritional quality of greenhouse spinach through biostimulant action. Agronomy 2018, 8, 126. [CrossRef]

20. Sestili, F.; Rouphael, Y.; Cardarelli, M.; Pucci, A.; Bonini, P.; Canaguier, R.; Colla, G. Protein hydrolysate stimulates growth in tomato coupled with $\mathrm{N}$-dependent gene expression involved in $\mathrm{N}$ assimilation. Front. Plant Sci. 2018, 9, 1233. [CrossRef]

21. Carillo, P.; Colla, G.; El-Nakhel, C.; Bonini, P.; D’Amelia, L.; Dell'Aversana, E.; Pannico, A.; Giordano, M.; Sifola, M.I.; Kyriacou, M.C.; et al. Biostimulant application with a tropical plant extract enhances Corchorus olitorius adaptation to sub-optimal nutrient regimens by improving physiological parameters. Agronomy 2019, 9, 249. [CrossRef]

22. Carillo, P.; Colla, G.; Fusco, G.M.; Dell'Aversana, E.; El-Nakhel, C.; Giordano, M.; Pannico, A.; Cozzolino, E.; Mori, M.; Reynaud, H.; et al. Morphological and physiological responses induced by protein hydrolysate-based biostimulant and nitrogen rates in greenhouse spinach. Agronomy 2019, 9, 450. [CrossRef]

23. Caruso, G.; Stoleru, V.; De Pascale, S.; Cozzolino, E.; Pannico, A.; Giordano, M.; Teliban, G.; Cuciniello, A.; Rouphael, Y. Production, leaf quality and antioxidants of perennial wall rocket as affected by crop cycle and mulching type. Agronomy 2019, 9, 194. [CrossRef]

24. Caruso, G.; De Pascale, S.; Cozzolino, E.; Cuciniello, A.; Cenvinzo, V.; Bonini, P.; Colla, G.; Rouphael, Y. Yield and nutritional quality of Vesuvian Piennolo tomato PDO as affected by farming system and biostimulant application. Agronomy 2019, 9, 505. [CrossRef]

25. Schiavon, M.; Ertani, A.; Nardi, S. Effects of an alfalfa protein hydrolysate on the gene expression and activity of enzymes of the tricarboxylic acid (TCA) cycle and nitrogen metabolism in Zea mays L. J. Agric. Food Chem. 2008, 56, 11800-11808. [CrossRef] [PubMed]

26. Matsumiya, Y.; Kubo, M. Soybean peptide: Novel plant growth promoting peptide from soybean. In Soybean and Nutrition; El-Shemy, H., Ed.; InTech Europe Publisher: Rijeka, Croatia, 2011; pp. 215-230. [CrossRef]

27. Colla, G.; Rouphael, Y.; Canaguier, R.; Svecova, E.; Cardarelli, M. Biostimulant action of a plant-derived protein hydrolysate produced through enzymatic hydrolysis. Front. Plant Sci. 2014, 5, 448. [CrossRef] [PubMed]

28. Colla, G.; Rouphael, Y.; Lucini, L.; Canaguier, R.; Stefanoni, W.; Fiorillo, A.; Cardarelli, M. Protein hydrolysate-based biostimulants: Origin, biological activity and application methods. Acta Hortic. 2016, 1148, 27-34. [CrossRef]

29. Battacharyya, D.; Babgohari, M.Z.; Rathor, P.; Prithiviraj, B. Seaweed extracts as biostimulants in horticulture. Sci. Hortic. 2015, 196, 39-48. [CrossRef] 
30. Sady, W.; Smoleń, S. The Influence of Pentakeep $V$ and Nitrogen Fertilization on the Yield and Biological Quality of Carrot and Spinach Crop; Final Report for Cosmo Oil Co., Ltd.; Cosmo Oil Co., Ltd.: Tokio, Japan, 2007.

31. Smoleń, S.; Sady, W. The influence of nitrogen fertilization and Pentakeep V application on contents of nitrates in carrot. Acta Hortic. Regiotec. 2009, 12, 221-223.

32. Smoleń, S.; Sady, W.; Wierzbińska, J. The effect of plant biostimulation with 'Pentakeep V' and nitrogen fertilization on yield, nitrogen metabolism and quality of spinach. Acta Sci. Pol. Hortorum Cultus 2010, 9, 25-36.

33. Paul, K.; Sorrentino, M.; Lucini, L.; Rouphael, Y.; Cardarelli, M.; Bonini, P.; Reynaud, H.; Canaguier, R.; Trtílek, M.; Panzarová, K.; et al. Understanding the biostimulant action of vegetal-derived protein hydrolysates by high-throughput plant phenotyping and metabolomics: A case study on tomato. Front. Plant Sci. 2019, 10, 47. [CrossRef] [PubMed]

34. Paul, K.; Sorrentino, M.; Lucini, L.; Rouphael, Y.; Cardarelli, M.; Bonini, P.; Miras Moreno, M.B.; Reynaud, H.; Canaguier, R.; Trtílek, M.; et al. A combined phenotypic and metabolomic approach for elucidating the biostimulant action of a plant-derived protein hydrolysate on tomato grown under limited water availability. Front. Plant Sci. 2019, 10, 493. [CrossRef] [PubMed]

35. Re, R.; Pellegrini, N.; Proteggente, A.; Pannala, A.; Yang, M.; Rice-Evans, C. Antioxidant activity applying an improved abts radical cation decolorization assay. Free Rad. Biol. Med. 1999, 26, 1231-1237. [CrossRef]

36. Fogliano, V.; Verde, V.; Randazzo, G.; Ritieni, A. Method for measuring antioxidant activity and its application to monitoring the antioxidant capacity of wines. J. Agric. Food Chem. 1999, 47, 1035-1040. [CrossRef] [PubMed]

37. Lichtenthaler, H.K.; Buschmann, C. Chlorophylls and Carote-Noids-Measurement and Characterisation by UV-VIS.-Cur-rent Protocols in Food Analytical Chemistry (CPFA), (Sup-plement 1), F4.3.1-F4.3.8; John Wiley: New York, NY, USA, 2001. [CrossRef]

38. Sah, R.N. Nitrate-nitrogen determination: A critical review. Commun. Soil Sci. Plant Anal. 1994, 25, $2841-2869$. [CrossRef]

39. Kampfenkel, K.; Van Montagu, M.; Inzé, D. Extraction and determination of ascorbate and dehydroascorbate from plant tissue. Anal. Biochem. 1995, 225, 165-167. [CrossRef]

40. Colla, G.; Cardarelli, M.; Bonini, P.; Rouphael, Y. Foliar applications of protein hydrolysate, plant and seaweed extracts increase yield but differentially modulate fruit quality of greenhouse tomato. HortScience 2017, 52, 1214-1220. [CrossRef]

41. Trevisan, S.; Manoli, A.; Quaggiotti, S.A. Novel biostimulant, belonging to protein hydrolysates, mitigates abiotic stress effects on maize seedlings grown in hydroponics. Agronomy 2019, 9, 28. [CrossRef]

42. Szczepanek, M.; Siwik-Ziomek, A. P and K accumulation by rapeseed as affected by biostimulant under different NPK and S fertilization doses. Agronomy 2019, 9, 477. [CrossRef]

43. Kyriacou, M.C.; Rouphael, Y.; Colla, G.; Zrenner, R.M.; Schwarz, D. Vegetable grafting: The implications of a growing agronomic imperative for vegetable fruit quality and nutritive value. Front. Plant Sci. 2017, 8, 741. [CrossRef]

44. Jannin, L.; Arkoun, M.; Etienne, P.; Laîné, P.; Goux, D.; Garnica, M.; Fuentes, M.; Francisco, S.S.; Baigorri, R.; Cruz, F. Brassica napus growth is promoted by Ascophyllum nodosum (L.) Le Jol. seaweed extract: Microarray analysis and physiological characterization of N, C, and S metabolisms. J. Plant Growth Regul. 2013, 32, 31-52. [CrossRef]

45. Ertani, A.; Schiavon, M.; Nardi, S. Transcriptome-wide identification of differentially expressed genes in Solanum Lycopersicon L. in response to an alfalfa-protein hydrolysate using microarrays. Front. Plant Sci. 2017, 8, 1159. [CrossRef] [PubMed]

46. Tsouvaltzis, P.; Koukounaras, A.; Siomos, S.A. Application of amino acids improves lettuce crop uniformity and inhibits nitrate accumulation induced by the supplemental inorganic nitrogen fertilization. Int. J. Agric. Biol. 2014, 16, 951-955. [CrossRef]

47. Colla, G.; Kim, H.J.; Kyriacou, M.C.; Rouphael, Y. Nitrate in fruits and vegetables. Sci. Hortic. 2018, 237, 231-238. [CrossRef]

48. Ali, M.; Cheng, Z.H.; Hayat, S.; Ahmad, H.; Ghani, M.I.; LIU, T. Foliar spraying of aqueous garlic bulb extract stimulates growth and antioxidant enzyme activity in eggplant (Solanum melongena L.). J. Integr. Agric. 2019, 18, 1001-1013. [CrossRef] 
49. Tadros, M.J.; Omari, H.J.; Turk, M.A. The morphological, physiological and biochemical responses of sweet corn to foliar application of amino acids biostimulants sprayed at three growth stages. Aust. J. Crop Sci. 2019, 13, 412-417. [CrossRef]

50. Khanam, U.K.S.; Oba, S.; Yanase, E.; Murakami, Y. Phenolic acids, flavonoids and total antioxidant capacity of selected leafy vegetables. J. Fun. Foods 2012, 4, 979-987. [CrossRef]

51. Kyriacou, M.C.; Rouphael, Y.; Di Gioia, F.; Kyratzis, A.; Serio, F.; Renna, M.; De Pascale, S.; Santamaria, P. Micro-scale food production and the rise of microgreens. Trends Food Sci. Technol. 2016, 57, 103-115. [CrossRef]

52. Kyriacou, M.C.; El-Nakhel, C.; Graziani, G.; Pannico, A.; Soteriou, G.A.; Giordano, M.; Ritieni, A.; De Pascale, S.; Rouphael, Y. Functional quality in novel food sources: Genotypic variation in the nutritive and phytochemical composition of thirteen microgreens species. Food Chem. 2019, 277, 107-118. [CrossRef]

53. Kyriacou, M.C.; Rouphael, Y. Towards a new definition of quality for fresh fruits and vegetables. Sci. Hortic. 2018, 234, 463-469. [CrossRef]

54. Rouphael, Y.; Kyriacou, M.C. Enhancing quality of fresh vegetables through salinity eustress and biofortification applications facilitated by soilless cultivation. Front. Plant Sci. 2018, 9, 1254. [CrossRef] [PubMed]

55. Wang, Z.H.; Li, S.X.; Malhi, S. Effects of fertilization and other agronomic measures on nutritional quality of crops. J. Sci. Food Agric. 2008, 88, 7-23. [CrossRef]

56. Vasantharaja, R.; Stanley Abraham, L.; Inbakandan, D.; Thirugnanasambandam, R.; Senthilvelan, T.; Ayesha Jabeen, S.K.; Prakash, P. Influence of seaweed extracts on growth, phytochemical contents and antioxidant capacity of cowpea (Vigna unguiculata L. Walp). Biocatal. Agric. Biotechnol. 2019, 17, 589-594. [CrossRef]

(C) 2019 by the authors. Licensee MDPI, Basel, Switzerland. This article is an open access article distributed under the terms and conditions of the Creative Commons Attribution (CC BY) license (http://creativecommons.org/licenses/by/4.0/). 